\title{
THE USAGE OF BORON/ BORON COMPOUNDS IN THE TEXTILE INDUSTRY AND ITS SITUATION IN TURKEY \\ Nihal Sokmen ${ }^{1}$, Banu Yeşim Buyukakinci ${ }^{2}$
}

\begin{abstract}
Commonly found in the earth's crust, boron happens to be the 51st element of the periodic table and is not found in its elemental state in nature. It is known that there are about 230 different boron minerals in nature. Turkey has the largest boron reserves in the world. In addition to this, Turkey's boron minerals have the highest quality and production conditions that are more economical than other boron producing countries. For this reason, boron has great importance for Turkey and there is a significant demand for new areas of usage so that Turkey would be able to contribute to the national economy with these resources. The institute of BOREN (National Boron Research Institute) was established for this purpose in Turkey. This institute funds related projects for the extension of boron usage areas. One of the open sectors for innovation is textile technology.

This study investigates the history of boron and its current situation in Turkey as well as the studies conducted regarding boron and its compounds especially in the textile field. Taking the available boron reserves in Turkey into consideration, the need for more research and development studies on boron as an environment-friendly element is clear for the textile industry.
\end{abstract}

UDC Classification: 677; DOI: http://dx.doi.org/10.12955/cbup.v6.1309

Keywords: Boron Minerals, Boron Sources, Eco-friendly materials, Textile sector.

\section{Introduction}

Commonly found in the soil, rocks and water, boron minerals exists naturally in soil on average at 10$20 \mathrm{ppm}$, in sea water at 0.5-9.6 ppm and in fresh water at 0.01-1.5 ppm. The element of boron is found in nature as minerals which are bonded to oxides of sodium, calcium and magnesium that contain crystal water (Duman, 2003). The most prevalent of raw boron and refined products in the world's boron sector are given in Table 1.

\begin{tabular}{|c|c|}
\hline \multicolumn{2}{|l|}{ Table 1: The most prevalent raw boron and refined products in the world } \\
\hline RAW BORON & REFINED PRODUCTS \\
\hline Tincal Concentrate & Borax Pentahydrate (Refined, Calcined) \\
\hline Ulexite Concentrate & Borax Decahydrate (Refined, Calcined) \\
\hline Colemanite Concentrate & Anhydrous Borax \\
\hline Granulated Colemanite & Boric Acid \\
\hline Hydroboracite Concentrate & Anhydrous Boric Acid \\
\hline Source: Güyagüler, 2001 \\
\hline
\end{tabular}

One widely-found boron mineral is Tourmaline which is an aluminoborosilicate mineral that may contain up to $10 \%$ of boron in its structure. However, the industry mostly uses the alkaline and alkaline earth minerals of tincal $\left(\mathrm{Na}_{4} \mathrm{~B}_{4} \mathrm{O}_{2} .10 \mathrm{H}_{2} \mathrm{O}\right)$, kernite $\left(\mathrm{Na}_{2} \mathrm{~B}_{4} \mathrm{O}_{7} .4 \mathrm{H}_{2} \mathrm{O}\right)$, colemanite $\left(\mathrm{Ca}_{2} \mathrm{~B}_{6} \mathrm{O}_{11} .5 \mathrm{H}_{2} \mathrm{O}\right)$ and ulexite $\left(\mathrm{NaCaB}_{5} \mathrm{O}_{9} .8 \mathrm{H}_{2} \mathrm{O}\right)$ (BOREN,2012; Etimaden 2014).

Being used in hundreds of different fields from the detergent industry to space technology, the element of boron has a strategic significance especially for Turkey. It is known that the life-span of boron reserves outside Turkey will last only 50 years. On the other hand, Turkey possesses boron reserves that can satisfy the demands of the entire world for 450-500 years. Considering these reserves and the increases in the consumption of these reserves, it is very likely that the Turkey's boron reserves will become the sole boron resources in the world within 50 to 80 years (Güyagüler, 2001; Acarkan, 2017; Kılıç, 2004)

\section{History of Boron}

Boron and its compounds have been known about and used for a long time. It is believed that Babylonia imported boron from the Far East for the gold industry 4000 years ago, and borax was used for mummification, treatment and metallurgical implementations in ancient Egypt. (BOREN, 2012). It is known that borax was used in the vicinity of Mecca and Medina in the 8th century and the mineral was

\footnotetext{
${ }^{1}$ Department of Textile Engineering, Technology Faculty, Marmara University, Istanbul, Turkey. nsokmen@gmail.com

2 Department of Textile Engineering, Engineering Faculty, Istanbul Aydın University, Istanbul, Turkey, byesimb2@gmail.com
} 
brought by Arab merchants, and Arabs also produced medicine from boron salts in the year 875 . It is believed that the oldest source for borax was Tibetan lakes and that borax was carried to India over the Himalayas with sheep, and the ore was thought to be brought from Tibet to Europe during the 13th century by Marco Polo (Woods, 1994).

It was understood that sassolite $\left(\mathrm{H}_{3} \mathrm{BO}_{3}\right)$ was found in the geysers of the Tuscany region of Italy in 1771 . The first boric acid production begun in 1830 in Italy and the first instance of borax mining in an industrial sense started in 1852 in Chile. After the discovery of the deposits in California in 1864 and in Nevada, Calico Mountains and Kramer later, the US became the main country that satisfies the boron needs of the world (MTA, 1976).

The isolation of elemental boron by putting boric acid $\left(\mathrm{H}_{3} \mathrm{BO}_{3}\right)$ into a reaction with potassium was achieved in the early nineteenth century by the French scientists Joseph Louis Gay-Lussac and Louis Jacques Thenard as well as separately by the English scientist Sir Humphrey Davy around the same date. Today, boron is usually obtained by heating borax $\left(\mathrm{Na}_{2} \mathrm{~B}_{4} \mathrm{O}_{7} \cdot 10 \mathrm{H}_{2} \mathrm{O}\right)$ with carbon.

\section{The situation of boron minerals in Turkey}

It is estimated that boron ores have been known and used in Turkey since the times of the Eastern Roman Empire. Maadin Nizamnamesi (Charter of Mines) was introduced in 1861 and starting from 1865 the business privileges of the boron minerals in Turkey was transferred to a French company for the following 20 years. The first boron mineral deposits were encountered in the Sultançayırı region of the Susurluk district of the city of Balıkesir.

The ore was a calcium salt and it was processed for a long time by foreign companies as pandermite. After the year 1944, a large number of these companies were nationalized, and no new privileges were given to foreign companies. After the nationalization of the privileges of foreign companies, the boron mines started to be operated by Etibank and some small-scaled local firms (BOREN, 2012).

\begin{tabular}{|l|c|c|}
\hline \multicolumn{2}{|l|}{ Table 2: The ratios of boron reserves in the world } \\
\hline COUNTRY & $\begin{array}{c}\text { TOTAL RESERVE } \\
\left(\mathbf{1 0 0 0} \text { tons } \mathbf{B}_{2} \mathbf{O}_{\mathbf{3}}\right)\end{array}$ & $\begin{array}{c}\text { TOTAL RESERVE } \\
\left(\mathbf{\%} \mathbf{B}_{\mathbf{2}} \mathbf{O}_{\mathbf{3}}\right)\end{array}$ \\
\hline TU & 953300 & 72.8 \\
\hline RUSSIA & 100000 & 7.6 \\
\hline USA & 80000 & 6.1 \\
\hline CHINA & 47000 & 3.6 \\
\hline CHILE & 41000 & 3.1 \\
\hline SERBIA & 24000 & 1.8 \\
\hline PERU & 22000 & 1.7 \\
\hline BOLIVIA & 19000 & 1.5 \\
\hline KAZAKHSTAN & 15000 & 1.1 \\
\hline ARGENTINA & 9000 & 0.7 \\
\hline TOTAL & 1310300 & 100.0 \\
\hline Source: Acarkan, 2017 & & \\
\hline
\end{tabular}

While the boron reserves in Turkey were thought to be around 600 million tons in the year 1978, due to recent research it was determined that Turkey has more around 3 billion tons of boron reserves. Reserve studies continue with the collaboration of Eti Maden/MTA. In the 1970s, Turkey had 16\% market share of the Boron market however, that increased to $47 \%$ which is what it is today, surpassing U.S.A and thus becoming the largest borate producer in the world(BOREN, 2012). Table 2 shows that highly concentrated boron deposits in the form of minerals formed by boron and oxygen are found mostly in some dry, volcanic and hydrothermal regions of Turkey, Russia, USA, China, Kazakhstan, Bolivia, Argentina, Peru and Chile.

Holding $72 \%$ of the world's known boron reserves, Turkey's known boron deposits are found especially in the regions of Kırka/Eskişehir, Bigadiç/Balıkesir, Kestelek/Bursa and Emet/Kütahya. The most frequently extracted boron ores in Turkey are tincal $\left(\mathrm{Na}_{2} \mathrm{O} \cdot 2 \mathrm{~B}_{2} \mathrm{O}_{3} \cdot 10 \mathrm{H}_{2} \mathrm{O}\right)$ and colemanite $\left(2 \mathrm{CaO} .3 \mathrm{~B}_{2} \mathrm{O}_{3} .5 \mathrm{H}_{2} \mathrm{O}\right)$. In Turkey, significant tincal deposits are found in Kurka whereas colemanite 
deposits are found around Emet, Bigadiç and Kestelek. In addition to this, there is a small ulexite reserve in Bigadiç, and ulexite is occasionally obtained as a by-product in Kestelek.

\section{Usage Areas of Boron}

The area where boron minerals are used most frequently (52\%) is the glass industry (Figure 1). Boric oxide is an important component of borosilicate glass, textile glass fiber and isolation-type glass fiber. Boron compounds are used in special oven containers, laboratory materials, headlight and indicator classes of cars, fiber glass, LCD (Liquid Crystal Display) screens and CRT glass products as well as in the production of some special types of glass in the space industry, electronics industry and nuclear reactors (BOREN, 2012; Yenialaca, 2009). In the ceramic industry, boron minerals are generally used in the production of ceramic glaze, and at the stage of frit production in making of porcelain enamel (Bilgiç \& Dayık, 2013)

\begin{tabular}{|l|l|l|}
\hline \multicolumn{2}{|c|}{ Figure 1: Distribution of boron consumption based on final areas of usage } & \\
\hline & Boron Areas of Usage & m glass \\
& & \\
& & \\
\hline
\end{tabular}

The boron mineral colemanite reduces the clinker firing temperature by $8 \%$ in cement production, and it is known to improve cement qualities. Boron cement shows better characteristics than Portland cement with respect to parameters such as durability, water and gas permeability, and heat of hydration. Low heat of hydration substantially reduces the need for cooling especially in mass concretes (Demirel \&Nasiroğlu, 2017).

Colemanite usage in cement production also reduces the amount of carbon dioxide emission into the atmosphere by $25-30 \%$. Boron cement production has the potential of being a lifeline for the sector in the framework of the responsibilities brought by the Kyoto protocol (BOREN, 2012). Due to their antiseptic, water-softening and bleaching effects boron minerals are added to soaps and detergents (Özpeker, 2017). Borates have started to be used as flame-retardants in various materials such as wood, cellulosic insulation, PVC and textile. Boron suppresses combustion by covering the surface of the burning material in a way that breaks its contact with oxygen. Disodium octaborate tetrahydrate can successfully be used in the long-term protection of wood from fungi and insects. This material may be applied on timber very easily via spraying, painting or pressure without needing to take any particular precautions (BOREN, 2012). Zinc borate is used in plastic materials; soluble borates such as boric acid, borax pentahydrate and borax decahydrate, on the other hand, are used in cellulosic materials. These materials are wood, plywood, wood fiber, paper and natural fibers such as cotton. Studies on nutrition and physiology of vegetables has shown that boron substantially improves the growth and quality of vegetables (BOREN, 2012). Boron is an indispensable micro nutrient for fruit trees regarding their blooming, fruit yielding and fruit quality. It is observed in the recent studies that spraying boron on the leaves increased the fruit yield in certain types of fruit trees. The addition of boron increases the hardness and durability of steel. Steels may contain boron up to the level of $50 \mathrm{ppm}$. Ferro-boron is used in the production of steel, cast iron, permanent magnets and amorphous metals (Özpeker, 2017). While boron chemicals may be used as rocket fuel, there are studies on potential usage of borohydrides like hydrogen diborane $\left(\mathrm{B}_{2} \mathrm{H}_{6}\right)$ and hydrogen pentaborane $\left(\mathrm{B}_{5} \mathrm{H}_{9}\right)$ in airplanes as high-performance fuel. Boron fibers are used in various areas from sports equipment to fishing, golfing, skiing, cycling, and space and aerial 
vehicles. Composites with boron content consist of polymer resins reinforced with boron fibers however high costs of boron fibers limit their areas of usage.

Sodium borohydride which is the most significant borohydride that is produced, used commercially and known to be a good carrier and storage intermediary of hydrogen, is currently used in several industrial areas including bleaching of paper stock, reduction of textile wastes and removal of heavy metals from wastewaters. Sodium borohydride is more advantageous over other substances with respect to hydrogen storage due to its characteristics of being non-flammable/non-explosive, environment-friendly, and the possibility of sodium meta-borate that is formed as a result of its reaction to be converted back into sodium borohydride. Sodium borohydride is expected to be an important product the energy field after hydrogen usage as a fuel becomes prevalent.

Stainless boron steels that are used as neutron absorbents in nuclear reactors contain boron carbides and titanium-boron alloys. Additionally, the boron ore colemanite is used for the storage of nuclear waste. Boron is a nutrient that is needed by the human body in minimal amounts and it is required to be taken from outside through foods as it cannot be synthesized in cells. In addition to adjusting the balance of calcium, magnesium and phosphorus in the metabolism, boron also helps in the formation of healthy bones and contributes to the improvement of muscle and brain functions ${ }^{3}$.

\begin{tabular}{|l|l||}
\hline \multicolumn{2}{|l||}{ Table 3: Usage Areas of Boron Ores and its Products } \\
\hline Calcium Sodium Borate Ores & Cellulosic - isolation - Fiberglas - Metallurgy - Nuclear - Glass \\
\hline Sodium Borate Ores & Refined borax pentahydrate - borax decahydrate - anhydrous borax \\
\hline $\begin{array}{l}\text { Borax Pentahydrate } \\
\text { Borax Decahydrate } \\
\text { Anhydrous Borax }\end{array}$ & $\begin{array}{l}\text { Fertilizer - Fiberglas - isolation - Metallurgy - Glass bleaches - Glass } \\
\text { Adhesives - Cosmetics and Drugs - Agriculture - Textile dyes -Leathers - } \\
\text { Wool preservative - Enamel - glaze - Photography }\end{array}$ \\
\hline Anhydrous Boric Acid & $\begin{array}{l}\text { Antiseptic - Cosmetics - Fire extinguisher - Leather - Insect control - } \\
\text { Metallurgy - Nylon and textile industry - Glazing - Soaps and detergents - } \\
\text { Photography }\end{array}$ \\
\hline Sodium Perborate & \begin{tabular}{l} 
Detergent - Bleachers - Disinfectants - Textile dyes - Glass \\
\hline Boric Acid
\end{tabular} \\
$\begin{array}{l}\text { Glass - Pest control - Insecticide - Insect Control - Photography - Soaps } \\
\text { and Detergents - Nylon - Textile Dyes - Wax softener - Wood preservative } \\
\text { - Glazing - Antiseptic - Cosmetics - Fire Extinguisher - Metallurgy - } \\
\text { Nuclear - Textile - Textile fiberglas }\end{array}$ \\
\hline Source: Absalom, 1979; Özpeker, 2017
\end{tabular}

Boron is actively used in the treatments of osteoporosis, allergic diseases, psychiatry, bone development and arthritis and menopause. Moreover, although not being a precise treatment, the element boron plays an important role in the elimination of cancer cells without harming healthy cells with Boron Neutron Capture Therapy (BNCT) and is seen as a new hope in the treatment of cancer (BOREN,2017; Yiğitbaşıŏglu, 2004).

A study conducted by Türkez H. et al. on boron reports that various boron compounds in low dosages were helpful in supporting antioxidant enzyme activities in human blood cultures, and while creating oxidative stress in increased dosages, boron compounds did not have genotoxic effects even in the highest dosages (Türkez et al., 2007). In another study by Türkez on boron, it was argued that boron compounds increased DNA resistance against the genotoxic effects of titanium dioxide Türkez, 2008). Usage Areas of Boron Ores and its Products are seen together in Table 3.

\section{Boron Studies in the Textile Field}

Although there are various studies conducted with boron compounds in the field of textile, it is generally seen that these studies have mostly utilized the flame retardancy of boron compounds (Kalin, 2008; Durgun, 2010)

In a study in this field, boric acid, borax and zing borate were added in three different ratios $(5 \%, 7.5 \%$, $10 \%$ ) onto a fire-retardant chemical named Alfa-x, and the study investigated whether this increased the flame retardancy of a cotton fabric or not. As a result of the statistical analyses, it was concluded that boron compounds increased the flame retardancy quality of the fabric, and borax provided the most effective result. It was determined that the quality of the flame retardancy provided highly effective results in studies where boron compounds were applied on cellulosic fabrics along with nitrogen (X ie 
et al.,2013). In a study with a similar purpose, a dyeing process was completed by adding differing amounts of boric acid and borax into a disperse colorant solution in order to give flame retardancy to a polyester fabric. The highest levels of flame retardancy was achieved in the dyeing process where 30 $\mathrm{g} / \mathrm{L}$ of boric acid was added (Gemci, 2010). As a result of testing the solutions of different concentrations prepared with boric acid and sodium borate on polyester and cotton fabrics, it was found that flame retardancy increased in the fabrics (Younis, 2016; Buyukakınc1, 2017; Akarslan, 2015). In a study where a solution consisting of boric acid $\left(\mathrm{H}_{3} \mathrm{~B} 0_{3}\right)$, urea $\left(\mathrm{CO}\left(\mathrm{NH}_{2}\right)_{2}\right)$ and tetraetoksisilan (TEOS) was applied on a silk fabric as a finishing, it was reported that the fabric gained perfect flame retardancy by a LOI value of $34.6 \%{ }^{25}$. In another study, after applying a finishing process on wool by preparation of sols where boric acid, zing borate and ammonium borate were added and tetraethyl silicate was used as a starter, it was observed that the fabric gained superior thermal stability and quality of flame retardancy ${ }^{26}$. The purpose of the study by Cavdar et al. was to investigate the effects of boron-based fire-retardants and glass fiber loading on the mechanical, combustion and thermal characteristics of polyethylene composites filled with impregnated spruce wood flour. With this study, it was demonstrated that borax was especially effective as a fire retardancy material for plastic composites reinforced by wood flour (Çavdar et al., 2015).

In another study, different boron compounds were used with the purpose of giving fire retardance properties to propylene composites and epoxy-based composites and their effects were investigated (Doğan et al, 2010; Doğan, 2014; Unlu et al., 2014). In Armitag's study, polymers [Polystyrene, poly (vinyl alcohol) v epoly (ethylene-co-vinyl alcohol)] were modified with reactive groups containing boron, and as a result of this, it was seen that their fire retardancy characteristics were improved and LOI index values increased (Armitage, 1996).

Some studies utilized the antibacterial characteristics of boron compounds. Towards this purpose, a sodium pentaborate pentahydrate and triclosan solution was applied on cotton fabrics. The antimicrobial activity of textiles was investigated against various microorganisms including bacteria, fungi and molds. According to the results, the modified textile products had much better antimicrobial and antiviral properties. Therefore, it was proposed that textiles processed with sodium pentaborate pentahydrate and triclosan solution may be considered in developing antimicrobial and antiviral textile surfaces (Iyigündoğdu et al., 2017). Despite the antibacterial properties of boron-based compounds are wellknown, the studies on pure boron nanoparticles are limited. In the study cited here, boron nanoparticles were characterized in terms of particle size, shape, stability and surface load before and after applying on textile surfaces in order to investigate their effects on antibacterial activity, as well as cytotoxicity. It was found that boron nanoparticles are effective in limiting reproduction of both gram-negative and gram-positive bacteria without the need for a stimulant to start antibiotic response (Akbar et al., 2015)

There are studies in the textile industry on alternative reducing agent usage. Especially studies on the reducing and bleaching effects of the compound $\mathrm{NaBH}_{4}$ (sodium borohydride) recently gained importance. Additionally, as it is environment-friendly, the interest in $\mathrm{NaBH}_{4}$ is growing increasingly.

The use of sodium borohydride in aqueous solutions provides various advantages. This is because sodium borohydride has a potential to be stored in alkaline solutions and the usually non-toxic environmental effects of sodium metaborate $\mathrm{NaBO}_{2}$ and its hydrates that are formed in the hydrolysis of sodium borohydride are minimal (Dinçer et al., 2015).

In a study by Meksi et al., sodium borohydride was used as a reducing agent instead of sodium dithionite during the dyeing of cotton with indigo. The results demonstrated a satisfactory quality in dyeing (Meksi et al., 2007).

In another study during the dyeing of cotton with Sulfur Black I, it was reported that the reducing system based on hydrazine sulphate, glucose and sodium borohydride reached the same color that was expected at the results of reduction where sodium sulfite was used (Yao et al., 2015).

In another study, after polyester fabrics were dyed with disperse colorant, reduction cleaning was carried out with two different reducing agents, sodium dithionite and sodium borohydride, and no significant difference was observed in the results (Büyükakınc1 et al., 2016).

In Y1lmazer and Kanık's study, unprocessed wool fabric was bleached by using sodium bisulfite (SBS) and sodium borohydride (SBH) together. The results were compared to the commercial bleaching method of bleaching with $\mathrm{H}_{2} \mathrm{O}_{2}$. The effects of concentration, bleaching time, $\mathrm{pH}$ and temperature on 
the bleaching process with SBH and SBS were investigated. In both bleaching methods; whiteness, yellowness and alkaline solubility results were analyzed, and the results showed that the whiteness levels obtained by bleaching with SBH were comparable to those in the $\mathrm{H}_{2} \mathrm{O}_{2}$ method (Y1lmazer \& Kanik, 2009).

The study by Sarina et al. used the method of reduction with sodium borohydride with bisulfite catalyst for reuse of wastewater in the textile industry. It was reported that the reduction process with sodium borohydride was successful in the removal of color although it did not satisfy the criteria necessary for the reuse of the water sufficiently (Sarina et al., 2006).

The necessity of further studies was emphasized for the more economical and effective implementation of the study on reduction of azo colorants in textile wastewater with borohydride/bisulfite and quaternary ammonium absorption (Laszlo, 1997).

In time, hydroxyl groups $(-\mathrm{OH})$ in cellulose fiber glass are turned into carbonyl groups $(=\mathrm{O})$, and as a result of this, a brown or yellow color is formed on the textile material and the physical characteristics of the textile are weakened. The process applied with borohydride may be a useful tool to reduce or eliminate yellowing without causing harmful side effects. Borohydride turns most aldehydes and ketones back into hydroxyls, and reverses oxidation to a certain extent. In a study conducted in this field, bleaching results were investigated on an artificially aged plain knit cotton fabric by changing factors such as the concentration of the borohydride solution, the duration of processing with borohydride, the $\mathrm{pH}$ of the solution, the removal of carboxylic acids before the process and the implementation methods (Ringgaard, 2002).

The use of boron compounds in different fields also attracts attention. For example, it was reported in Mario's studies that $\mathrm{NaOH}$ and $\mathrm{NaBH}_{4}$ were used together for improving the durability and matrixadhesiveness of sisal/polyester composites (Moares et al., 2012)

\section{Conclusion}

Possessing the world's largest boron reserves offers Turkey a significant advantage. Broadening the areas of usage for boron which still attracts limited consumption, and producing end products carries a vital importance. For this reason, the institute BOREN was established in 2003. The mission of the institute was described as: "The widespread usage of boron products and technologies in Turkey and abroad, provisioning the scientific environment required for the research of users by achieving production and improvement of new boron products, conduction, delegation, coordination of and contributions to scientific studies by collaborating with institutions or individuals who use boron and its products or do research in this field." In this context, there are several projects that were previously supported by the BOREN institute or are still ongoing.

As seen in the studies described above, the usage and importance of boron compounds, especially in manufacturing that require advanced technology, are increasing daily. In order for the world-wide boron market to be revived, it is necessary to bring rational approaches towards broadening the usage of boron into attention. An important issue concerning technological studies is environmental pollution. It is known that due to their environment-friendly characteristics, and studies on this issue, boron compounds are used in place of various substances that are harmful to the environment and the studies in this respect are increasingly gaining importance and support.

In addition to being environment-friendly, boron compounds have other significant characteristics that maintain its usage in the textile industry such as reduction, bleaching and fire retardancy as well as the quality of being antibacterial. In order to make use of these characteristics of boron, more studies are needed on this issue.

The textile sector is one of the leading sectors in Turkey. The inclusion of boron compounds in the process, especially in textile finishing operations, will increase the usage of boron not only in Turkey, but also around the world. Considering the large boron reserves in Turkey, preference of boron compounds will contribute to the economy of the country in addition to increasing environmental awareness.

\section{References}

Absalom ST. (1979). Boron, Mineral Commodity Summaries, U.S. Department of the Interior Bureau of Mines.

Acarkan N. (2002). Boron Products and Their Uses. Retrieved from 
http://www.maden.org.tr/resimler/ekler/0ae4561193dbf6e_ek.pdf.

Akarslan F. (2015). Investigation on Fire Retardancy Properties of Boric Acid Doped Textile Material, Acta Physica Polonica A, 128, 403.

Akbar W, Karagoz A, Basim G B, Noor M, Syed T, Lum J \& Unluagac M. (2015). Nano-boron as an Antibacterial Agent for Functionalized Textiles, MRS Online Proceedings Library Archive, 1793, 53-57. https://doi.org/10.1557/opl.2015.728.

Armitage P, Ebdon J R, Hunt B J, Jones M S \& Thorpe F G. (1996) . Chemical modification of polymers to improve flame retardance-1 The influence of boron-containing groups, Polymer Degradation and Stability, 54, 387-393.

Bilgiç M \& Dayık M. (2013). Boron Propeties and Its Advantages In Textile Industry, Electronic Journal of Textile Technologies, 7, No.2, 27-37.

BOREN. (2012) National Boron Research Institute, Retrieved from http://www.boren.gov.tr.

Buyukakinci BY., Y1lmaz A. (2017). Investigation of Boric Acid and Sodium Borate Effect on Flame Retardancy of Cotton and Polyester Fabrics, Asian Journal of Chemistry, 29, (4) 893-895.

Buyukakinci BY, Sokmen N \& Bayender B. (2016). Effect of sodium borhydride on microwave assisted reductive cleaning of dyed polyester fabrics, Asian Journal of Chemistry, 28, 2752-2754.

Cavdar A D, Mengeloglu F \& Karakus K (2015). Effect of boric acid and borax on mechanical, fire and thermal properties of wood flour filled high density polyethylene composites, Measurement, 60, 6-12.

Demirel B \& Nasıroğlu S. (2017). Stategies fort he Use of Boron Minerals ans Wastes in the Cement, Science and Eng. J. of Firat Univ. 29,(1), 95-100.

Dincer I, Colpan C O, Kizilkan O \& Ezan M A. (2015). Progress in Clean Energy, Novel Systems and Applications, Springer, 2. Edited .

Dogan M, Y1lmaz A \& Bayraml1 E. (2010). Synergistic effect of boron containing substances on flame retardancy and thermal stability of intumescent polypropylene composites. Polymer Degradation and Stability, 95, 2584-2588.

Dogan M \& Unlu S M, (2014). Flame retardant effect of boron compounds on red phosphorus containing epoxy resins, Polymer Degradation and Stability, 99, 12-17

Duman I. (2013). Bor madenleri ve stratejik bor ürünleri, Bilim ve Ütopya Dergisi 114, 18-21

Etimaden. (2014). Eti Maden Bor Sektörü Raporu, Eti Maden Stratejik Plan. Retrieved from http://www.etimaden.gov.tr/files/files/document/files/2014\%20YILI\%20BOR\%20SEKT\%C3\%96R\%20RAPORU.pdf Durgun G. (2010). Synthesis of Various Calcium Borates, Characterization and Investigation of Flame Retardant Effenciencies, Master Thesis, Ankara University.

Eti Maden Stratejik Plan (2015-2019) Retrieved from http://www.etimaden.gov.tr/files/files/document/files/Stratejik_plan_2015_2019.pdf

Gemci R, Gülşen G. (2010). Güç Tutuşur Kumaş Üretiminde Bor Bileşiklerinin Kullanılması, Tekstil Teknolojileri Elektronik Dergisi, 4(1) 1-10.

Güyagüler T. (2001). Türkiye Bor Potansiyeli, 4.Endüstriyel Hammaddeler Sempozyumu,18-19 Oct.2001, İzmir, Türkiye.

Iyigundogdu Z U, Demir O \& Asutay A B. (2017). Developing Novel Antimicrobial and Antiviral Textile Products, Applied Biochemistry and Biotechnology, 181 (3) 1155-1166.

Kalın B M. (2008.). Improving Fire Retardancy Specify of Textile Surfaces, Master Thesis, Kahramanmaraș Sütçü Imam Üniversitesi, Tekstil Mühendisliği, Kahramanmaraş.

Kılıç A M.(2004). Importance of Boron Mine for Turkey and Place in the Future, II. Uluslararası Bor sempozyumu, 23-25 Sept 2004. Eskişehir, Turkey.

Laszlo JA. (1997). Regeneration of Dye-Saturated Quaternized Cellulose by Bisulfite-Mediated Borohydride Reduction of Dye Azo Groups: An Improved Processs for Decolorization of Textile Eastewaters, Environ. Sci. Technol., 31, 3647-3653.

Meksi N, Kechida M \& Mhenni F. (2007). Cotton dyeing by indigo with the borohydride process: Effect of some experimental conditions on indigo reduction and dyeing quality, Chemical Engineering Journal 131, 187-193.

Moares A.G.O. (2011), Sierakowski M R, Abreu T M \& Amico S C, Sodium Borohydride as a Protective Agent for the Alkaline Treatment of Sisal Fibers for Polymer Composites, Composite Interfaces, 18, 407-418.

Moares A.G.O. (2012). Sierakowski M R \& Amico S C, The Novel Use of Sodium Borohydride as a Protective Agent for the Chemical Treatment of vegetable Fibers, Fibers and Polymers, 13 (5) 641-646.

MTA. (1976). Türkiye Bor Mineralleri Envanteri, MTA yayınları, 162, 52.

Özpeker I. (2017). Bor'un Kullanımı, Tüketimi ve Ulusal Gelire Katkı Olanağı. Retrieved from http://www.maden.org.tr/resimler/ekler/d0cb12f8c9ad684_ek.pdf.

Ringgaard M. (2002). An Investigation of the Effects of Borohydride treatments of Oxidized Cellulose Textiles. In: Strengthening the Bond: Science and Textiles, North American Textile Conservation Conference. 91 - 101

Sarina J E, Theerriault B M \& Reckow D A. (2006). Evalution of Water Reuse Technologies for the Textile Industry, Journal of Environmental Engineering, 132 (3) 315-323.

Türkez H. (2008). Effects of boric acid and borax on titanium dioxide genotoxicity, Journal of Applied Toxicology 28, (5), 658-664. 
Türkez H, Geyikoğlu F, Tatar A, Keleş S \& Özkan A. (2007). Effects of some boron compounds on peripheral human blood, Zeitschrift fur Naturforschung Journal of Biosciences, (62), 889-896.

Unlu S M, Dogan S D \& Dogan M. (2014), Comparative study of boron compounds and aluminum trihydroxide as flame retardant additives in epoxy resin, Polym. Adv. Technol, 25, 769-776.

Woods WG. (1994).An Introduction to Boron: History, Sources, Uses, and Chemistry, Environmental Health Perspectives, 102, 5-11.

Xie K, Gao A \& Zhang Y. (2013). Flame retardant finishing of cotton fabric based on synergistic compounds containing boron and nitrogen, Carbohydrate Polymers, 98, 706.

Yao J, Dou C, Wei S \& Zheng M. (2015). Using ecological reducing agents instead of sodium sulphide in dyeing with CI Sulphur Black 1, Coloration Technology, 131, 379-383.

Yenialaca Ç.(2009). Bor ve Kullanım Alanları, Master Thesis, Gazi University, Ankara.

Y1lmazer D \& Kanık M. (2009). Bleaching of wool with sodium borohydride, Journal of Engineered Fibers and Fabrics, 4, 45-50.

Yiğitbaşığlu H.(2004). Türkiye İçin Önemli Bir Maden: Bor, Coğrafi Bilimler Dergisi. 2: 13-25. Retrieved from http://dergiler.ankara.edu.tr/dergiler/33/825/10467.pdf .

Younis AA. (2016). Evaluation of the flammability and thermal properties of a new flame retardant coating applied on polyester fabric, Egyptian Journal of Petroleum,25,(2), 161-169.

Zhang Q, Chen G \& Xing T. (2017). Silk flame retardant finish by ternary silica sol containing boron and nitrogen, Applied Surface Science.

Zhang Q, Zhang W, Huang J, Lai Y, Xing T, Chen G, Jin W, Liu H \& Sun B. (2015). Flame retardance and thermal stability of wool fabric treated by boron containing silica sols, Materials and Design, 85, 796-799. 